\title{
Risk factors related to resistance to Rhipicephalus (Boophilus) microplus and weight gain of heifers
}

\section{Fatores de risco relacionados à resistência a Rhipicephalus (Boophilus) microplus e ganho de peso de bezerras}

\author{
Jenevaldo Barbosa da Silva ${ }^{1 *}$; José Diomedes Barbosa²; \\ Adivaldo Henrique Fonseca ${ }^{3}$
}

\begin{abstract}
The aim of the present study was to evaluate the influence of age and genetics in dairy heifers on resistance to the cattle tick Rhipicephalus (Boophilus) microplus and correlate these parameters with weight gain. Twenty-two heifers were evaluated from birth up to two years of age. Resistance to the cattle tick was evaluated by counting the number of engorged female ticks and subjective qualification of the larvae and nymph infestation. The animals were weighted in the first 24 hours after birth and at six, 12, 18 and 24 months of age. The average tick count and weight gain were compared by Tukey's test at $5 \%$ significance. Subsequently, linear regression was performed to verify the strength of the association between the risk factors age and genetics and infestation by $R$. (B.) microplus. Age and genetics were both significant risk factors for $R$. (B.) microplus infestation in heifers. Between the third and sixth months of age, the animals showed a window of susceptibility to $R$. (B.) microplus. Regardless of age, Bos taurus heifers had higher infestations than Bos indicus, crossbred F1 $(1 / 2$ B. taurus $\times 1 / 2 B$. indicus) and crossbred Gir-Holstein (Girolando) ( $5 / 8$ B. taurus $\times 3 / 8$ B. indicus) heifers. B. taurus heifers were heavier than $B$. indicus heifers at birth and had significantly greater weight gain $(\mathrm{p}<0.01)$.

Key words: Bos indicus, Bos taurus, weight gain, resistance, Rhipicephalus microplus
\end{abstract}

\section{Resumo}

O objetivo do estudo foi conhecer a influência da idade e da genética sobre a resistência ao carrapato Rhipicephalus (Boophilus) microplus e correlacionar estes parâmetros com ganho de peso de bezerras de origem leiteira. Foram avaliadas 22 bezerras desde o nascimento até dois anos de idade. A avaliação da resistência foi realizada por meio da contagem de teleóginas ingurgitados e qualificação subjetiva da infestação por larvas e ninfas. Os animais foram pesados nas primeiras 24 horas pós-nascimento, aos seis, 12, 18 e 24 meses de idade. A comparação das médias das contagens de carrapatos e ganho de peso foi realizada pelo teste Tukey a $5 \%$ de significância. Posteriormente foi realizada regressão linear para verificar a força da associação entre os fatores de risco idade e genética e a infestação por $R$. (B.) microplus. A idade e a genética constituíram importantes fatores de risco para infestação por $R$. (B.) microplus nas bezerras. Entre o terceiro e sexto mês de idade, os animais apresentaram uma janela de suscetibilidade ao carrapato $R$. (B.) microplus. Independente da idade, bezerras Bos taurus foram mais infestadas do que bezerras Bos indicus, mestiças F1 ( $1 \frac{2 B}{B}$. taurus $\times 1 / 2 B$. indicus) e Girolandas $(5 / 8 B$.

\footnotetext{
${ }^{1}$ Discente, Dept ${ }^{\circ}$ de Patologia Veterinária, Faculdade de Ciências Agrárias e Veterinárias, Universidade Estadual Paulista, FCAV/ UNESP, Jaboticabal, SP, Brasil. E-mail: jenevaldo@hotmail.com

2 Prof., Dept ${ }^{\circ}$ de Ciência Animal, Universidade Federal do Pará, UFPA, Castanhal, PA, Brasil. E-mail: diomedes@ufpa.br

${ }^{3}$ Prof., Dept ${ }^{\circ}$ de Epidemiologia e Saúde Pública, Universidade Federal Rural de Rio de Janeiro, UFRRJ, Seropédica, RJ, Brasil. E-mail: adivaldo@ufrrj.br

* Author for correspondence
} 
taurus $\mathrm{x} 3 / 8$ B. indicus). Além de nascerem mais pesadas, as bezerras $B$. taurus demonstraram ganho de peso significativamente maior $(\mathrm{p}<0.01)$ do que as bezerras $B$. indicus.

Palavras-chave: Bos indicus, Bos taurus, ganho de peso, resistência, Rhipicephalus microplus

Cattle infestation by the Rhipicephalus microplus tick has caused significant losses to the livestock industry (JONSSON, 2006). It is estimated that the economic losses caused by $R$. (B.) microplus worldwide can reach 13 billion dollars annually, and in Brazil alone, this value can exceed 800 million dollars (MARTINEZ et al., 2006). These economic losses are mainly associated with the ingestion of host blood, toxin inoculation, decreased leather quality and the transmission of pathogenic agents, especially protozoans of the genera Anaplasma and Babesia (TURNER; SHORT, 1972; SUTHERST et al., 1983; SILVA et al., 2013, 2014).

Host susceptibility to parasites is a multifactorial phenomenon in which distinct characteristics can be recognized such as the host immune response, age and genetics (CONSTANTINOIU et al., 2010). The first immunity of newborns against parasitic agents is the immunity provided by colostral antibodies, which is an important factor for the establishment of the host-parasite balance. Maternal antibodies in calves usually disappear 9-12 weeks after birth; however, calves remain resistant for a longer period (POTGIETER; STOLTZ, 1994).

Zebu and taurine breeds are equally susceptible to primary infestation by $R$. (B.) microplus larvae (WAGLAND, 1975; SILVA et al., 2013). The greater resistance level in Zebu cattle becomes apparent after a period of susceptibility to primary infestation (HEWETSON, 1971). Studies have demonstrated greater resistance to cattle ticks in Zebu cattle compared with taurine animals (PIPER et al., 2009; CONSTANTINOIU et al., 2010). This difference has also been demonstrated in crossbred animals in which greater proportions of Zebu blood are associated with greater resistance to the cattle tick (JONSSON, 2006).
The economic damage caused by the cattle tick to cattle and the rational use of acaricides can be determined by counting the number of engorged females (SUTHERST et al., 1983). Jonsson (2006) estimated that the economic loss caused by each engorged female is $1.25 \mathrm{~g}$ of bodyweight for both Bos taurus and Bos indicus. Thus, especially in tropical regions where pure B. taurus cattle have largely been replaced by $B$. indicus and their crossbreeds, knowledge of the parasite load is very important to determine the genetic patterns of herds. In this context, the aim of the present study was to evaluate the influence of age and genetics as risk factors for resistance to $R$. (B.) microplus and weight gain in dairy heifers.

Field activities were performed from 2008 to 2010 in the Dairy Cattle Division (Setor de Bovinocultura de Leite) of the State Center for Research in Organic Agriculture (Centro Estadual de Pesquisa em Agricultura Orgânica) from the Agricultural Research Corporation of the State of Rio de Janeiro (Empresa de Pesquisa Agropecuária do Estado do Rio de Janeiro - Pesagro-Rio), located in the metropolitan microregion of the municipality of Rio de Janeiro (latitude $22^{\circ} 45^{\prime} \mathrm{S}$, longitude $43^{\circ} 41^{\prime} \mathrm{W}$ and 33 meters altitude).

Twenty-two heifers were evaluated from birth up to two years of age. The evaluated animals remained in the same pasture and were maintained under the same husbandry management throughout the experimental period. The animals were randomly selected by stratified sampling. Of all the animals evaluated, six were $B$. taurus calves, six were crossbred F1 $(1 / 2 B$. taurus $\times 1 / 2 B$. indicus) calves, five were Gir-Holstein crossbred (Girolando) ( $5 / 8$ B. taurus x $3 / 8$ B. indicus) calves and five were $B$. indicus calves. 
After birth, the heifers remained in individual pens for the first 15 days of life, being fed with milk twice a day (4 $\mathrm{kg}$ of milk/day). After this period, the animals continued to be fed with milk and were moved to a 0.5 hectare (ha) paddock with Brachiaria humidicola pasture until they were four months old. From four to 12 months of age, the animals were kept in an area measuring three ha with Brachiaria decumbens and Panicum maximum pasture. When they were one year old, they were transferred to an agro-forestry-pastoral system measuring 5 ha, where they remained until they were two years old. $R$. microplus infestation was controlled with mineral salt containing DIFLY S3® (a chitin synthesis inhibitor), which was supplied daily in the feeding trough ad libitum. For helminth control, the animals received quarterly IVOMEC ${ }^{\circledR}$ (ivermectin, $1 \mathrm{mg}$ / $\mathrm{kg}$, Merial, Brazil). For hemoparasite control, animals with clinical signs of anaplasmosis or babesiosis were treated with TERRAMICINA $\AA$ (oxytetracycline, $20 \mathrm{mg} / \mathrm{kg}$, Ouro Fino, Brazil) and IMIZOL ${ }^{\circledR}$ (imidocarb dipropionate, $2.1 \mathrm{mg} / \mathrm{kg}$, Bayer, Brazil).

Resistance to the cattle tick was evaluated by counting the number of ticks in naturally infested animals using the method described by Wharton and Utech (1970). All the fully or partially engorged females of $R$. (B.) microplus (between 4.5 and 8.0 $\mathrm{mm}$ in length) on one side of the animal's body were counted, and then, the number was multiplied by two.

The animals were separated into four categories according to their $R$. (B.) microplus infestation level: absence of adult ticks, nymphs and larvae; low infestation (between 1 to 10 engorged females and few larvae and nymphs); intermediate infestation (between 11 and 30 engorged females and an intermediate number of larvae and nymphs); and high infestation (more than 31 engorged females and several larvae and nymphs).

To monitor weight, the animals were weighed within the first 24 hours after birth and at six, 12, 18 and 24 months of age. The daily average weight gain (DAWG) was calculated using the following formula: DAWG (kg/day) = (weaning weight - birth weight $) \div$ number of days between weaning and birth.

Because the characteristics studied did not fit a normal probability distribution, they were transformed to $\log _{10}(\mathrm{n}+1)$. The variable average number of $R$. (B.) microplus for each age group and genetic group was subjected to analysis of variance. Subsequently, the means were compared by Tukey's test at 5\% significance. The data were subjected to linear regression analysis to quantify the strength of the association between variables. The statistical analyses were performed using the software R Foundation for Statistical Computing, version 2.12.2 (R DEVELOPMENT CORE TEAM, 2011).

Age was an important risk factor for $R$. (B.) microplus infestation level. One-day-old to twomonth-old heifers had low levels of parasitism, with an average of 10 engorged females and a low larvae/nymphs infestation. A significant increase $(\mathrm{p}<0.05)$ in the $R$. (B.) microplus infestation as a function of age was observed, and the three- to sixmonth-old animals showed the greatest parasitism, with an average of 31 engorged females and a high larvae/nymphs infestation. Among the seven- to 12-month-old animals, moderate infestation was observed, with 15 engorged females on average and an intermediate larvae/nymphs infestation. Animals older than one year of age had a low infestation, with an average of 12 engorged females and a low larvae/nymphs infestation (Figure 1).

The blood proportion significantly $(\mathrm{p}<0.05)$ influenced $R$. (B.) microplus infestation in the heifers (Figure 1). Throughout the study, the $B$. taurus heifers were more infested (38 engorged females and a high larvae/nymphs infestation) than $B$. indicus (six engorged females and a low larvae/ nymphs infestation), Girolando (10 engorged females and an intermediate larvae/nymphs infestation) and crossbred F1 (17 engorged females and an intermediate larvae/nymphs infestation) heifers. A positive correlation (0.96) was observed 
between the level of $R$. (B.) microplus infestation and a greater proportion of $B$. taurus blood.

The highest average infestation was observed in three- to six-month-old B. taurus heifers (90 engorged females and a high larvae/nymphs infestation), and the lowest average infestation was found in $B$. indicus heifers older than 12 months (one engorged female and a low larvae/nymphs infestation).

Figure 1. Average number of Rhipicephalus microplus ticks on 22 heifers, Pesagro-Rio, 2008-2010. A - Number of $R$. (B.) microplus according to age during the first two years of life. $\mathbf{B}$ - Number of $R$. (B.) microplus according to the breed of dairy cattle.
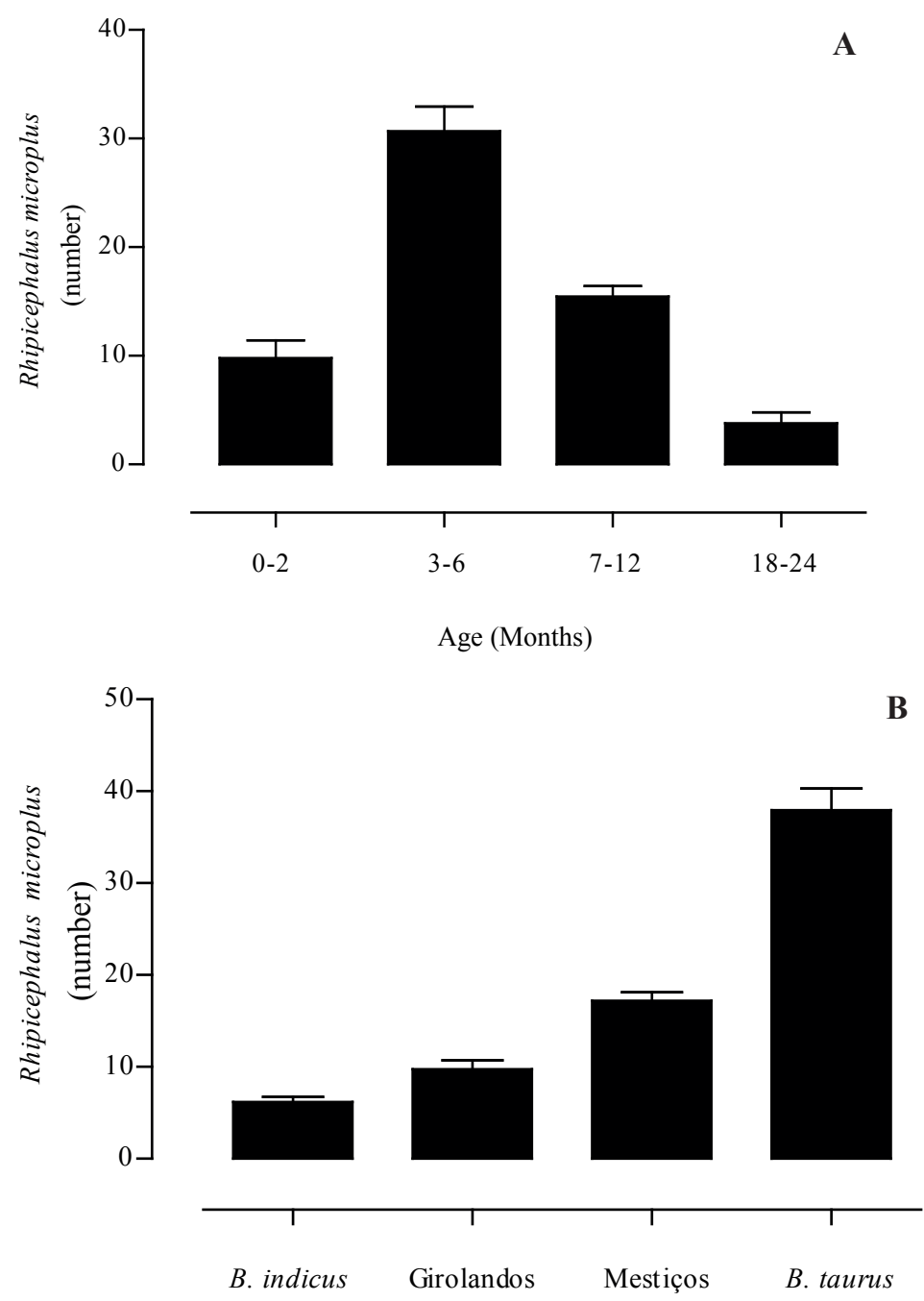

Breed

The heifers' weights at birth and at six, 12, 18 and 24 months by genetic group are shown in Table 1. Pure B. taurus animals showed significantly greater DAWG $(\mathrm{p}<0.05)$ than $B$. indicus animals.
Although the B. taurus heifers were the heaviest at birth and had a higher DAWG throughout the study, there was no significant difference $(\mathrm{p}>$ $0.05)$ between the $B$. taurus heifers and the two 
groups of crossbred animals.

At the end of the 24 months, the average weights (DAWG) of the B. taurus, F1, Girolando and $B$. indicus heifers were $208 \mathrm{~kg}$ (285 g/day), $190 \mathrm{~kg}$ (260 g/day), $187 \mathrm{~kg}(256 \mathrm{~g} /$ day) and $182 \mathrm{~kg}(249$ $\mathrm{g} /$ day), respectively. At the end of the evaluation period, the $B$. taurus heifers had gained $32 \mathrm{~kg}$ more than $B$. indicus heifers on average.

The influence of age on cattle resistance to $R$. (B.) microplus ticks has been reported by other authors (VERÍSSIMO et al., 1997; ANDRADE et al., 1998). The present study agrees with Veríssimo et al. (1997), who observed that lactating or very young heifers are more resistant to ticks due to the passive immunity transmitted by cows via colostrum. These authors also found that the animals became less resistant over the subsequent months, passing through a phase of high susceptibility during puberty before ultimately stabilizing their resistance once the active immune response was established.

Table 1. Average weight change in 22 animals according to age and breed, Pesagro-Rio, 2008-2010. The Bos taurus (Holstein), F1 crossbreed ( $1 / 2$ B. taurus x $1 / 2$ B. indicus), Gir-Holstein crossbreed (Girolando) $(5 / 8$ B. taurus x $3 / 8$ B. indicus) and B. indicus (Gir) animals were weighed every six months for two years.

\begin{tabular}{lccccc}
\hline \multirow{2}{*}{ Breeds } & \multicolumn{5}{c}{ Weight of heifers } \\
\cline { 2 - 5 } & Birth & 6 months old & 12 months old & 18 months old & 24 months old \\
\hline Bos taurus & $32 \pm 3.4^{\mathrm{A}}$ & $125 \pm 5.4^{\mathrm{A}}$ & $150 \pm 4.7^{\mathrm{A}}$ & $180 \pm 4.5^{\mathrm{A}}$ & $240 \pm 6.3^{\mathrm{A}}$ \\
F1 & $30 \pm 3.8^{\mathrm{A}}$ & $120 \pm 3.5^{\mathrm{AB}}$ & $140 \pm 4.2^{\mathrm{AB}}$ & $170 \pm 4.8^{\mathrm{AB}}$ & $220 \pm 4.3^{\mathrm{AB}}$ \\
Girolando & $28 \pm 4.8^{\mathrm{AB}}$ & $115 \pm 3.9^{\mathrm{AB}}$ & $132 \pm 3.6^{\mathrm{AB}}$ & $165 \pm 3.8^{\mathrm{AB}}$ & $215 \pm 4.4^{\mathrm{AB}}$ \\
Bos indicus & $26 \pm 2.3^{\mathrm{B}}$ & $110 \pm 3.2^{\mathrm{B}}$ & $117 \pm 3.6^{\mathrm{B}}$ & $154 \pm 3.3^{\mathrm{B}}$ & $208 \pm 3.5^{\mathrm{B}}$ \\
\hline
\end{tabular}

Different letters in the columns indicate a significant difference by the Kruskal-Wallis test at $5 \%$ probability.

All the animals were susceptible to $R$. (B.) microplus from one to 24 months of age; however, $B$. taurus animals remained vulnerable throughout the first year of life, whereas $B$. indicus animals became resistant after the first infestations. Several authors have demonstrated the higher resistance of Zebu cattle to $R$. (B.) microplus compared with taurine cattle (PIPER et al., 2009, 2010; CONSTANTINOIU et al., 2010) and their crossbreeds (JONSSON, 2006). Zebu and taurine cattle without previous contact with $R$. (B.) microplus are equally susceptible to primary infestation (WAGLAND, 1975). Therefore, the higher resistance level of Zebu animals becomes apparent after a period of susceptibility to initial $R$. microplus infestation (HEWETSON, 1971).

Acquired immunity combined with selection for resistant animals and management practices such as rotational grazing have been proposed as viable methods for tick control because they reduce the use of acaricides (FRISCH, 1999). B. indicus breeds are more resistant to $R$. (B.) microplus than $B$. taurus breeds, although this resistance can vary between breeds and individuals (SEIFERT, 1971; WHARTON; UTECH, 1970; SILVA et al., 2014). An animal's resistance to tick infestation has high heritability, with estimated rates of 39\% - 49\% for B. taurus (WHARTON et al., 1970) and 82\% for B. indicus (SEIFERT, 1971). Thus, selection of individual animals of $B$. taurus and B. indicus breeds can be an important tool in the sustainable control of ticks in the tropics.

B. taurus animals had higher weight gains, despite being significantly more parasitized. These results are likely explained by the genetic characteristics of $B$. taurus animals and the low parasitism shown by all the studied animals. According to Jonsson 
(2006), each $R$. (B.) microplus engorged female is responsible for a 0.25 to $1.37 \mathrm{~g}$ reduction in the bodyweight of B. taurus cattle. In crossbred animals, this reduction ranges from 0.21 to 1.18 $\mathrm{g}$ of bodyweight per tick. According to Jonsson (2006), these values are not statistically significant, indicating that $B$. taurus animals and crossbreds are equally harmed by $R$. (B.) microplus.

Under the management conditions adopted in the present study, four- to six-month-old heifers and animals of the $B$. taurus breed were more susceptible to the $R$. (B.) microplus tick. Regardless of age, $B$. taurus calves had greater weight gain than $B$. indicus calves.

\section{References}

ANDRADE, A. B. F.; SILVA, R. G.; COSTA, A. J.; ROCHA, U. F.; LANDIM, V. J. C. Genetic and environmental aspects of the resistance of Zebu cattle to the tick Boophilus microplus. In: WORLD CONGRESS ON GENETICS APPLIED TO LIVESTOCK PRODUCTION, 6., 1998, Armidale. Proceedings... Armidale: University of New England, 1998. p. 339-342.

CONSTANTINOIU, C. C.; JACKSON, L. A.; JORGENSEN, W. K.; LEW-TABOR, A. E.; PIPER, E. K.; MAYER, D. G.; VENUS, B.; JONSSON, N. N. Local immune response against larvae of Rhipicephalus (Boophilus) microplus in Bos taurus indicus and Bos taurus taurus cattle. International Journal for Parasitology, Cairns, v. 40, n. 7, p. 865875, jun. 2010.

FRISCH, J. E. Towards a permanent solution for controlling cattle ticks. International Journal for Parasitology, Cairns, v. 29, n. 1, p. 57-71, jan. 1999.

HEWETSON, R. W. Resistance by cattle to the cattle tick, Boophilus microplus - III. The development of resistance to experimental infestations by purebred Sahiwal and Australian Illawarra shorthorn cattle. Australian Journal of Agricultural Research, Cairns, v. 22, n. 2, p. 331-342, 1971.

JONSSON, N. N. The productivity effects of cattle tick (Boophilus microplus) infestation on cattle, with particular reference to Bos indicus cattle and their crosses. Veterinary Parasitology, Amsterdam, v. 137, n. 1, p. 1-10, abr. 2006.
MARTINEZ, M. L.; MACHADO, M. A.; NASCIMENTO, C. S.; SILVA, M. V. G. B.; TEODORO, R. L.; FURLONG, J.; PRATA, M. C. A.; CAMPOS, A. L.; GUIMARÃES, M. F. M.; AZEVEDO, A. L. S.; PIRES, M. F. A.; VERNEQUE, R. S. Association of BoLA-DRB3. 2 alleles with tick (Boophilus microplus) resistance in cattle. Genetics and Molecular Research, Ribeirão Preto, v. 5, n. 3, p. 513-524, ago. 2006.

PIPER, E. K.; JACKSON, L. A.; BIELEFELDTOHMANN, H.; GONDRO, C.; LEW-TABOR, A. E.; JONSSON, N. N. Tick-susceptible Bos taurus cattle display an increased cellular response at the site of larval Rhipicephalus (Boophilus) microplus attachment, compared with tick-resistant Bos indicus cattle. International Journal for Parasitology, Cairns, v. 40, n. 4, p. 431-441, mar. 2010.

PIPER, E. K.; JONSSON, N. N.; GONDRO, C.; LEWTABOR, A. E.; MOOLHUIJZEN, P.; VANCE, M. E.; JACKSON, L. A. Immunological profiles of Bos taurus and Bos indicus cattle infested with the cattle tick, Rhipicephalus (Boophilus) microplus. Clinical and Vaccine Immunology, Washington, v. 16, n. 7, p. 10741086, jun. 2009.

POTGIETER, F. T.; STOLTSZ, W. H. Anaplasmosis. In: COETZER, J. A. W.; THOMPSON, G. R.; TUSTIN, R. C. (Ed.). Infectious diseases of livestock: with special reference to Southern Africa. Cape Town: Oxford University Press, 1994. p. 408-430.

R DEVELOPMENT CORE TEAM. R: a language and environment for statistical computing. Vienna: $\mathrm{R}$ Foundation for Statistical Computing, 2011. Available at: $<$ http://www.R-project.org>. Accessed at: 20 fev. 2011.

SEIFERT, G. W. Variations between and within breeds of cattle in resistance to field infestations of the cattle tick (Boophilus microplus). Australian Journal Agricultural Research, Cairns, v. 22, n. 1, p. 159-168, 1971.

SILVA, J. B.; RANGEL, C. P.; BAÊTA, B. A.; FONSECA, A. H. Analysis of the risk factors relating to cows' resistance to Rhipicephalus microplus ticks during the peripartum. Experimental and Applied Acarology, Amsterdam, v. 63, n. 4, p. 551-557, 2014.

. Influence of the physiological state on infestation by Rhipicephalus microplus in dairy cows. Ticks TickBorne Diseases, Amsterdam, v. 4, n. 1-2, p. 52-56, 2013.

SUTHERST, R. W.; MAYWALD, G. F.; KERR, J. D.; STEGEMAN, D. A. The effect of cattle tick (Boophilus microplus) on the growth of Bos indicus x B. taurus steers. Australian Journal of Agricultural Research, Cairns, v. 34, n. 3, p. 317-327, 1983. 
TURNER, H. G.; SHORT, A. J. Effects of field infestations of gastrointestinal helminths and of the cattle tick (Boophilus microplus) on growth of three breeds of cattle. Australian Journal of Agricultural Research, Cairns, v. 23, n. 1, p. 177-193, 1972.

VERÍSSIMO, C. J.; SILVA, R. G.; OLIVEIRA, A. A. D.; RIBEIRO, W. R.; ROCHA, U. F. Resistência e susceptibilidade de bovinos leiteiros mestiços ao carrapato Boophilus microplus. Boletim de Indústria Animal, Nova Odessa, v. 54, n. 1, p. 1-10, 1997.
WAGLAND, B. M. Host resistance to cattle tick (Boophilus microplus) in Brahman (Bos Indicus) cattle. I. Responses of previously unexposed cattle to four infestations with 20. 000 larvae. Australian Journal of Agricultural Research, Cairns, v. 26, n. 6, p. 1073-80, 1975.

WHARTON, R. H.; UTECH, K. B. W. The relation between engorgement and dropping of Boophilus microplus (Canestrini) (lxodidae) to the assessment of tick numbers on cattle. Journal of the Australian Entomological Society, Cairns, v. 9, n. 1, p. 171-182, jul. 1970. 
